\title{
Feeding success of sperm whales and sea-surface temperature off the Galápagos Islands
}

\author{
Hal Whitehead ${ }^{1}$, Vassili Papastavrou ${ }^{2}$, Sean C. Smith ${ }^{3}$ \\ 1 Department of Biology, Dalhousie University, Halifax, Nova Scotia, Canada B3H 4J1 \\ 27 Hartington Park, Redland, Bristol BS6 7ES, England \\ ${ }^{3}$ Department of Biology, Acadia University, Wolfville, Nova Scotia, Canada BOP 1X0
}

\begin{abstract}
Sperm whales Physeter macrocephalus were observed off the Galápagos Islands between late February and April 1985, a year of cool sea-surface temperatures (SST), and January to June 1987, an 'El Niño' year of warm SST Distribution, abundance and diet of sperm whales were similar in both years. However, in 1987 they appeared to have a lower feeding success, as indicated by a reduced rate of observing faeces, and dived to shallower depths. Excretion rates were negatively correlated with sea-surface temperatures.
\end{abstract}

The 'El Niño' phenomenon, an irregular event in which exceptionally warm surface waters appear in the central and eastern tropical Pacific, has considerable effects on most marine life in the area (Merlen 1984, Arntz 1986, Barber \& Chavez 1986). El Niño is unfavourable to most pelagic species, but there is little information concerning its effects on mesopelagic species, largely because organisms in this depth range are hard to sample for biomass.

The sperm whale Physeter macrocephalus, which feeds in this ecosystem, has indirectly provided considerable information on mesopelagic squid through studies of stomach contents and diving behaviour (Clarke 1980). Recently, research on living sperm whales has also given results on sperm whale feeding behaviour and the ecosystems in which they feed (Gordon 1987, Papastavrou 1987).

In this note we relate indications of the feeding success of sperm whales around the Galápagos Islands to sea-surface temperature. We principally use data collected in 1985, a year of cool sea-surface temperatures (mean SST in early 1985 near Galápagos = $25.4^{\circ} \mathrm{C}$ ), and 1987, an 'El Niño' year (mean SST in early 1987 near Galápagos $=27.5^{\circ} \mathrm{C}$ ). We also summarize results on differences and similarities in the distribution, abundance and behaviour of the whales between the 2 years.
Research was carried out from a $10 \mathrm{~m}$ ocean-going sloop in the waters around the Galapagos Islands, Ecuador $\left(0^{\circ} \mathrm{N}, 91^{\circ} \mathrm{W}\right)$, between 23 February and 20 April 1985 (a total of $30 \mathrm{~d}$ spent tracking sperm whales) and 3 January and 28 June 1987 (57 d). Similar studies were made between 9 and 21 April 1988 from a $12 \mathrm{~m}$ auxiliary sloop. Groups of sperm whales were tracked by passively listening for their sounds using a directional hydrophone (Whitehead \& Gordon 1986).

The rate of observing faeces was used as an indicator of the feeding success of the whales. For this measure we only used faeces observed as the whales fluked-up at the start of a feeding dive, and calculated the proportion of fluke-ups observed within $250 \mathrm{~m}$ of the research vessel which were accompanied by a defaecation. This meant that defaecations during breaches (leaps from the water) and other energetic acitivity were not included. Such defaecations may be more related to physiology than feeding success. A total of 3921 fluke-ups were observed within $250 \mathrm{~m}$ of the research vessel, and of these 125 were accompanied by defaecations. Sea-surface temperatures were measured every $3 \mathrm{~h}$, but only 06:00 h readings are used in this paper, to avoid the effects of the warming of the surface layer by the sun. Rates of observing faeces and mean sea surface temperatures were calculated for each calendar month while in the Galápagos.

The rate at which we observed faeces was significantly, $\left(\chi^{2}{ }_{1}=21.96, p<0.01\right)$ higher in $1985(4.8 \%$ of fluke-ups observed with faeces) than in 1987 (2.1\% of fluke-ups observed with faeces). The rate of seeing faeces during each month was negatively correlated with the mean 06:00 h SST during that month (Fig. 1) and this relation is statistically significant $(r=-0.761$, $p=0.011$ ). Although the correlation appears depend- 


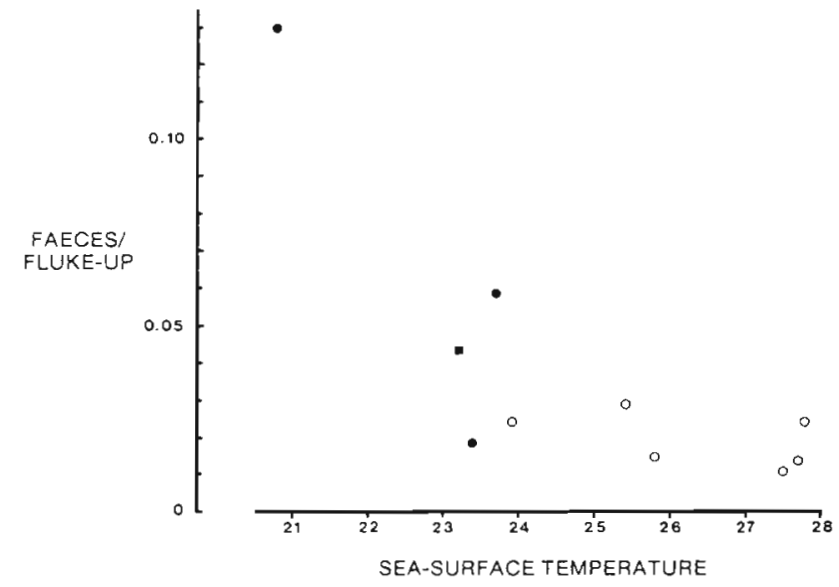

Fig. 1. Relationship between proportion of observed fluke-ups (within $250 \mathrm{~m}$ of the research vessel) accompanied by faeces and mean 06:00 h SST for each month of the 1985 study ( 1987 study (O), and 1988 study

ent on the point for February 1985, the coldest month of our studies and the one in which most faeces were seen, if this point is removed there is still a strong negative correlation $(r=-0.601, p=0.087)$.

There are physiological reasons for thinking that cetaceans may generally defaecate at the surface (Kooyman et al. 1981), and therefore that the rate of observing faeces may be indicative of feeding success. Faecal analyses have shown that in both 1985 and 1987 the sperm whales off the Galápagos were principally eating histioteuthid squid (Papastavrou 1987, S. C. Smith unpubl.), and densities of whales were similar in the 2 years (Whitehead et al. in press). Therefore, our results suggest that the availability of histioteuthids to sperm whales off the Galápagos is lowered during periods of high SST's.

SST in the Galápagos area is closely related to the presence of upwelling, as is primary production (Houvenaghel 1978). The most important upwelling off the Galápagos is caused by the Equatorial Undercurrent, which runs eastward beneath the Equator, and this undercurrent was disrupted during the 1982-83 El Niño (Feldman et al. 1984). Three possible reasons for the probable negative correlation between histioteuthid biomass and SST off the Galápagos are:

(1) The squid, because of decreased energy flow through the pelagic ecosystem, show slower growth, decreased reproduction or greater mortality (from sources other than sperm whales) when high SSTs lead to low primary production. If this were the principal reason for the changes in histioteuthid biomass we would expect a lag between the change in SST and squid biomass, as the decrease in productivity worked its way through the trophic system. However, the response of the whales' feeding success to changing
SST is fast (the faeces/fluke ratio dropped from 0.13 to 0.06 between February and March 1985 as the SST rose from $21^{\circ}$ to $24^{\circ} \mathrm{C}$ ). Therefore it seems possible that this trophic explanation for changes in histioteuthid biomass with SST is not sufficient.

(2) The histioteuthids in the general Galápagos area may redistribute themselves in a manner unfavourable to sperm whales during warm SST conditions. However, unlike some marine predators in the Galápagos area, the sperm whale is not tied to any land area, and should be able to track concentrations of its prey.

(3) The histioteuthids may be being brought to the Galápagos by the Equatorial Undercurrent, or possibly other currents. The decreased biomass of histioteuthids may be the result of the slowing of these currents during El Niños.

Whatever the causal relationship, it seems that the biomass of mesopelagic whale food off the Galápagos experiences variations with climatic events, such as El Niño, like the more familiar organisms of surface waters (Merlen 1984). We have found some differences in the behaviour of the whales between 1985 and 1987 which may be related to a change in the availability of their food. The depths of dive of sperm whales in 1985 were remarkably consistent at $420 \mathrm{~m}$; in 1987, dive depths were significantly shallower (mean $320 \mathrm{~m}$ ) and more variable (Papastavrou et al. in press). The rate at which whales breached was significantly lower in 1987 than 1985, but lobtailing, a less energetic aerial display in which the flukes are thrashed on the water surface, showed no such variation (Waters $\&$ Whitehead unpubl.). Foraging whales also changed direction more frequently in 1987 than 1985 (Whitehead in press). However, there were no major changes in the density or distribution of the Galápagos sperm whales like those found by Ramirez \& Urquizo (1985) for the Peruvian sperm whales in response to the 1982-83 'Super' El Niño.

Acknowledgements. We thank those who helped collect the data at sea, but especially T. Arnbom, A. Brooks, L. Fawcett, C. Hendrickson, B. Lambert, K. Lynch, C. Smythe, J. Staniforth, S Staniforth, S. Waters and L. Weilgart. The Charles Darwin Research Station, the Instituto Oceanográfico de la Armada, and the Galápagos National Park Service provided considerable assistance. The studies were funded by M. Clark, F. C. P. Whitehead, the Green Island Foundation, Connecticut Cetacean Society, the Natural Science and Engineering Research Council of Canada and the International Whaling Commission. World Wildlife Fund/I.U.C.N, loaned equipment for both studies.

\section{LITERATURE CITED}

Arntz, W. E. (1986). The two faces of El Niño 1982-83. Meeres forschung $31.1-46$

Barber, R. T., Chavez, F. P. (1986). Ocean variability in relation to living resources during the 1982-83 El Niño Nature, Lond. 319: 279-285 
Clarke, M. R. (1980). Cephalopods in the diet of sperm whales of the southern hemisphere and their bearing on sperm whale biology. 'Discovery' Rep. 37: 1-324

Feldman, G., Clark, D., Halpern, D. (1984). Satellite color observations of the phytoplankton distribution in the eastern equatorial Pacific during the 1982-1983 El Nino. Science 226: 1069-1071

Gordon, J. C. D. (1987). The behaviour and ecology of sperm whales off Sri Lanka. Ph. D. thesis, University of Cambridge

Houvenaghel, G. T (1978). Oceanographic conditions in the Galápagos Archipelago and their relationships with life on the islands. In: Boje, R., Tomczak, M. (eds) Upwelling ecosystems. Springer Verlag, New York, p. 181-200

Kooyman, G. L., Castellini, M. A., Davis, R. W. (1981). Physiology of diving in marine mammals. Ann. Rev. Physiol. 43: 343-356

Merlen, G. (1984). The 1982-83 El Niño: some of its consequences for Galápagos wildlife. Oryx 18(4): 210-214

Papastavrou, V. (1987). Feeding ecology of sperm whales

This note was presented by W. N. Bonner, Cambridge, UK
Physeter macrocephalus in the Galápagos Islands. M. Sc thesis, University of Bristol

Papastavrou, V., Smith, S. C., Whitehead, H. (in press). Diving behaviour of the sperm whale, Physeter macrocephalus, off the Galápagos Islands. Can. J. Zool. 67

Ramirez, P., Urquizo, W. (1985). Los cetaceos mayores y el fenómeno 'El Niño' 1982-83. In: Arntz, W., Landa, A. Tarazona, J. (eds.) El fenómeno El Nin̄o y su impacto en la fauna marina. Boln Inst. Mar. Peru (spec. issue), p. 201-206

Whitehead, H. (in press). Formations of foraging sperm whales, Physeter macrocephalus, of the Galapagos Islands. Can. J. Zool

Whitehead, H., Gordon, J. (1986). Methods of obtaining data for assessing and modelling sperm whale populations which do not depend on catches. Rep. int. Whal. Commn (spec. issue 8): 149-166

Whitehead, H., Weilgart, L. S., Waters, S. (in press) Seasonality of sperm whales off the Galápagas Islands, Ecuador. Rep. int. Whal. Commn

Manuscript first received: November 20,1988

Revised version accepted: February 2, 1989 